\title{
ON TROPICAL DROSERA ROTUNDIFOLIA L.
}

Andreas FleischmanN - Botanische Staatssammlung München and GeoBio-Center LMU University・Menzinger Strasse $67 \cdot$ D-80638 Munich・Germany・fleischmann@bio.lmu.de

Abstract: Two aspects on the morphology and biology of the Philippine population of D. rotundifolia were not answered by Coritico and Fleischmann (2016), namely its seed morphology and seasonal growth cycle - especially regarding hibernaculum formation, as it is known from its temperate congeners. These gaps can now be covered from observations made from cultivated plants and shall be reported here. Further aspects on the biology of Philippine D. rotundifolia (and other tropical populations of temperate Drosera) in cultivation and natural habitat are presented.

\section{Distribution and altitudinal range of Drosera rotundifolia}

The generic type species of Drosera, Drosera rotundifolia L., is probably the most well-known sundew species, at least to people from the Northern Hemisphere. It is also the most widespread ${ }^{1}$, its range spans the entire boreal region (Fig. 1; Meusel et al. 1965). Its southernmost populations in the Northern Hemisphere are situated in SE China, in the mountain ranges of northern Guangdong province, at ca. $24.5^{\circ} \mathrm{N}$ (Coritico \& Fleischmann 2016). In Europe its more or less continuous range reaches to ca. $39^{\circ} \mathrm{N}$ to the south in central Spain, in North America to ca. $34^{\circ} \mathrm{N}$ in northern Georgia and Alabama states, in Japan to $30^{\circ} \mathrm{N}$ on the island of Yakushima (Coritico \& Fleischmann 2016). Additionally, D. rotundifolia shows a few isolated outlier populations in some areas of the Mediterranean [e.g. on the isle of Corsica, France (Delange \& Hugot 2020), in the Sierra Nevada of southern Spain (Lorite 2016), and in northern Greece (just three sites known in the Rhodope Mountains; Theodoropoulos \& Eleftheriadou 2012)], in central Lebanon (Diels 1906; Tohmé \& Tohmé 2007; despite erroneous claims, e.g. by Walker 2015 or Baranyai \& Joosten 2016, the species is absent from Israel, misplaced records from "Israel" actually refer to the Lebanese populations), the western Caucasus (W Georgia; Fischer et al. 2018, and NE Turkey; Eminağaoğlu et al. 2008), in Colorado, USA (only four sites known in the Rocky Mountains; Rice 2019), as well in tropical latitudes on a single high

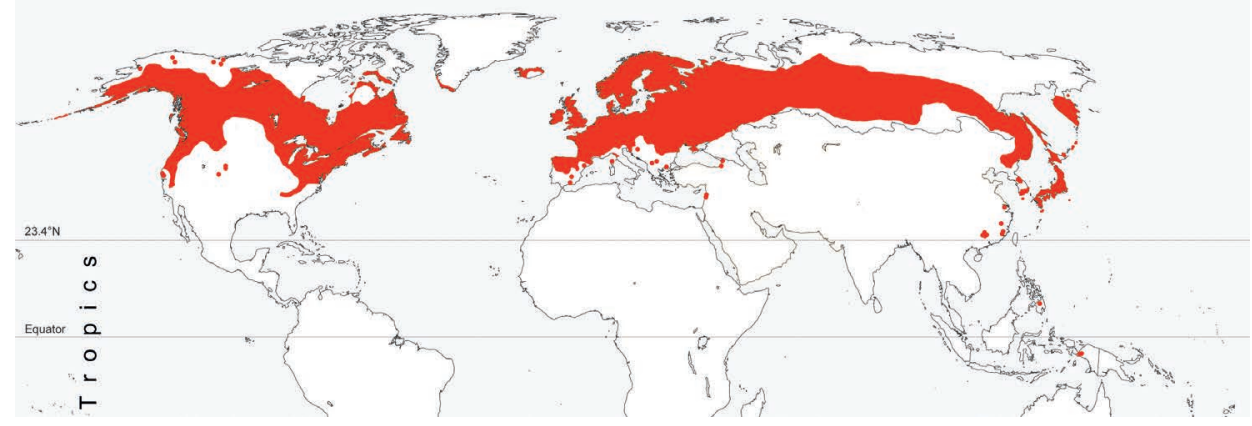

Figure 1: Global range of Drosera rotundifolia L. (based on herbarium records, Meusel et al. 1965, Hultén 1971, Schnell 2002, and Coritico \& Fleischmann 2016).

\footnotetext{
${ }^{1}$ Drosera rotundifolia has the largest global range, i.e. area of occupancy, of all Drosera species. Although D. intermedia covers a wider latitudinal range, that species has much smaller areal range.
} 
mountain summit of Mindanao island in the Philippines, and - as single occurrence across the equator - in Papua New Guinea (Coritico \& Fleischmann 2016; Fig. 1). Additionally, D. rotundifolia has been recently introduced (most likely accidentally by hikers) to the New World Southern Hemisphere in a Patagonian peatbog in Argentina (Vidal-Russell et al. 2019). Baranyai \& Joosten (2016) erroneously record the species for Cyprus (without further proof), as well as for southern parts of Texas, Mississippi, Alabama, Georgia, and northern Florida, where D. rotundifolia is absent and records are based on misidentified D. capillaris (Rice et al. 2017), or apparently even D. brevifolia.

In the Holarctic region, D. rotundifolia occurs from sea level in arctic, subarctic and northern coastal regions to up to 2000 m elevation in the European Alps (e.g., Wallnöfer \& Vitek 1999; a single outstanding locality at $2484 \mathrm{~m}$ : Lunghinsee, Switzerland; Maurizio 2009) and $2100 \mathrm{~m}$ in Spain (Paiva 1997), $1800 \mathrm{~m}$ at the Caucasian Black Sea coast (Eminağaoğlu et al. 2008), reaching $1500 \mathrm{~m}$ in mainland Asia (in China; Lu \& Kondo 2001), $2000 \mathrm{~m}$ in Japan (Diels 1906), and ca. 3000 $\mathrm{m}$ at high elevation peatbogs in Colorado, USA (Wolf et al. 2006). In the Southeast Asian tropics, it occurs at $1880 \mathrm{~m}$ on Mount Limbawon in the Philippines and at $1750 \mathrm{~m}$ at Paniai Lakes, Papua, Western New Guinea, Indonesia (Van Steenis 1955; Coritico \& Fleischmann 2016; C. Lee, pers. com. 2020).

Habitat of tropical D. rotundifolia and tropical populations of temperate species

I am frequently asked by carnivorous plant enthusiasts if the Papuan (and after its discovery also the Philippine) plants were indeed D. rotundifolia, or not a different but lookalike species. Although it might sound strange that a temperate bog species occurs on tropical mountain summits, this phenomenon is actually not uncommon in plants - other typical species of boreal flora are likewise commonly found on exposed high mountain summits above tropical rainforest, in Southeast Asia (see Van Steenis 1962, and Coritico \& Fleischmann 2016 for examples and explanations) as well as in tropical Africa, often of geologically young arrival (e.g., Assefa et al. 2007). Most likely, they reached these habitats by exceptional long-distance dispersal events by chance, and were able to survive and establish persistent populations in these cold tropical highland conditions, although not exposed to a seasonal climate anymore. Interestingly, Drosera rotundifolia is not the only temperate carnivorous plant species that reached the highlands of New Guinea, as Utricularia minor also has its single Southern Hemisphere occurrence there (Taylor 1977; Coritico \& Fleischmann 2016). That the Philippine and Papuan populations of that temperate Drosera species were accidentally or intentionally introduced (e.g. by hikers) can arguably be excluded, as both localities are quite remote and have not been visited by anyone except locals previous to the species' initial discoveries (Van Steenis 1955; Coritico \& Fleischmann 2016).

In the Philippines, $D$. rotundifolia is known only from a single, small high-altitude peat bog at Mt. Limbawon of the Pantaron mountain range in Bukidnon Province, Mindanao island. The plants occupy a single site, in an open area of just about 100 square meters, in a very wet montane Sphagnum bog surrounded by - and slowly overgrown by - dwarf mossy forest (Coritico \& Fleischmann 2016; D. Marwinski, pers. com. 2017). In contrast to its preferred sites in temperate regions, the Philippine plants grow in soaking wet peat moss, often partially submerged in seeping water (Fig. 2), accompanied by Xyris sp. (yellow-eyed grass; Xyridaceae) and juvenile plants of Nepenthes ceciliae and N. pulchra (Coritico \& Fleischmann 2016; Robinson et al. 2017; D. Marwinski, pers. com. 2017). In the New Guinean highlands, D. rotundifolia grows in similar conditions at a single high-elevation Sphagnum bog in the Paniai Lakes region (Fig. 3; Coritico \& Fleischmann 2016; C. Lee, pers. coms. 2007, 2020), accompanied by Xyris sp., clubmosses (Lycopodiaceae), bushes of 


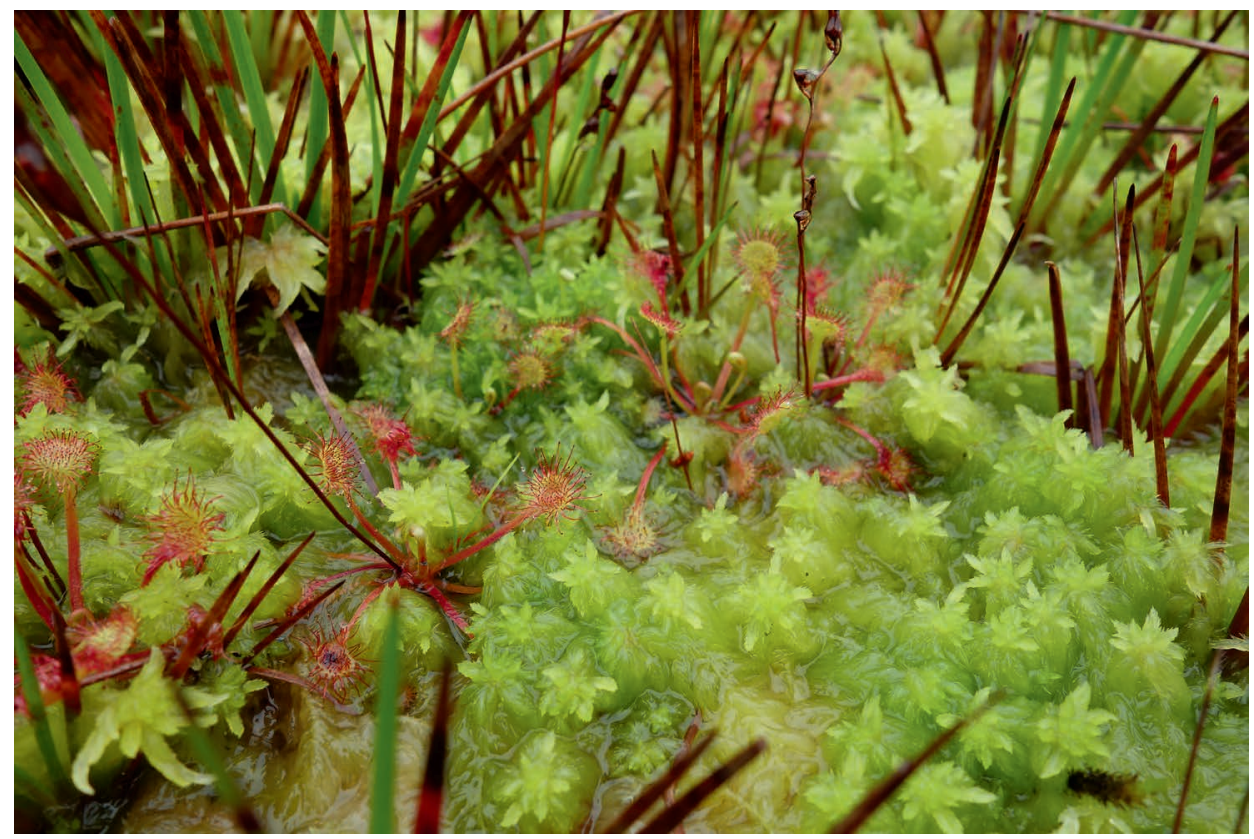

Figure 2: A tropical highland population of $D$. rotundifolia growing in a very wet montane Sphagnum bog on Mindanao, Philippines at 1880 m elevation, accompanied by Xyris sp. Photo: David Marwinski.
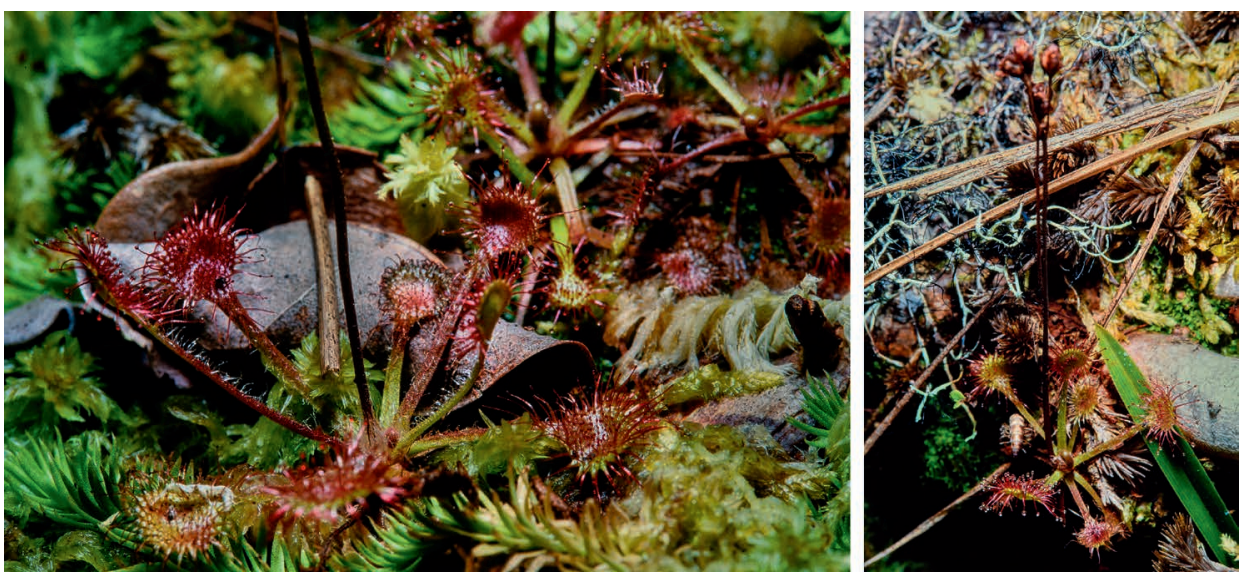

Figure 3: Drosera rotundifolia in a high-elevation peat bog in Papua (Irian Jaya), New Guinea, associated with Sphagnum sp. and Lycopodiella sp. Photos: Chien Lee.

Rhododendron spp. (Ericaceae), Papuacedrus papuana (Cupressaceae), Utricularia spp. and $\mathrm{Ne}$ penthes maxima (Fig. 4; C. Lee, pers. obs. 2004, 2006).

In general, the tropical Philippine and Papuan specimens of $D$. rotundifolia tend to have narrower (and a bit more roundish) laminas compared to their European and North American congeners (Fig. 5), which usually have leaf blades that are more transversely broadly elliptic in shape. However, the 


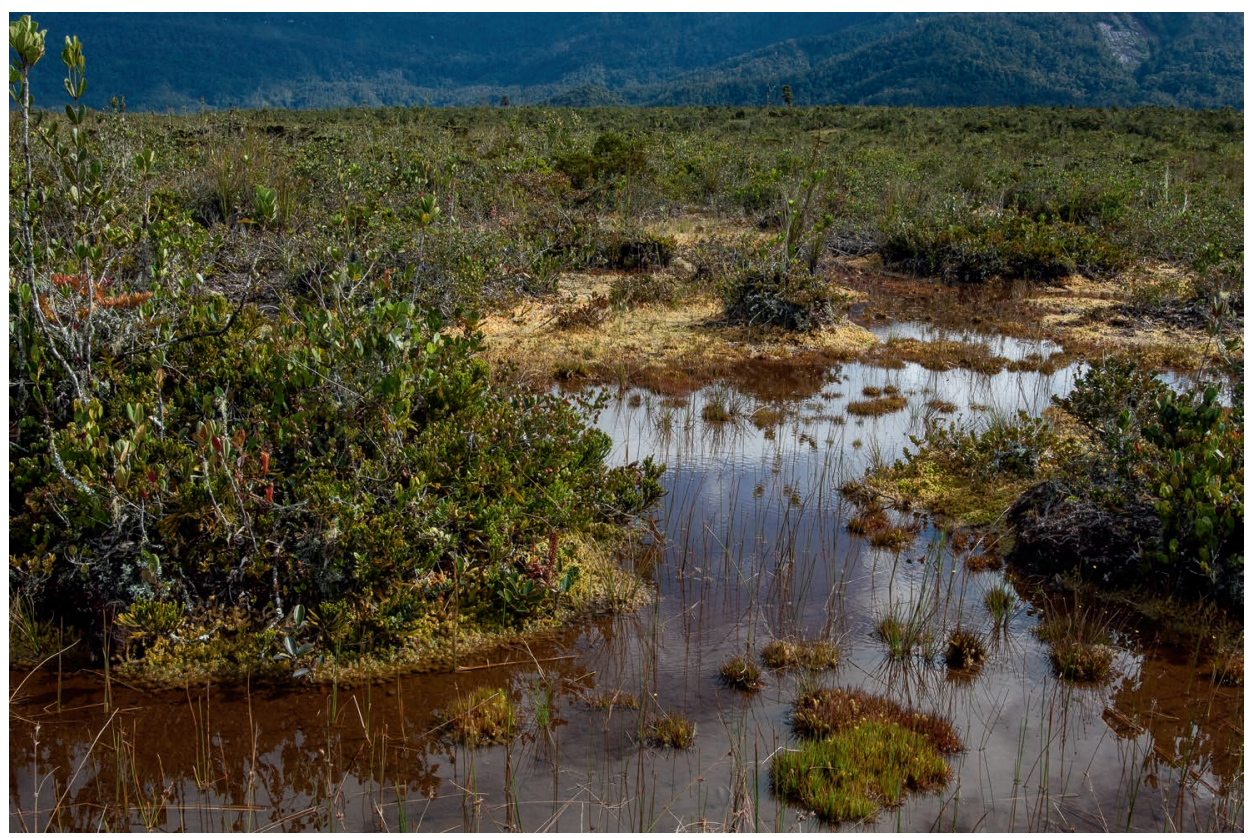

Figure 4: Habitat of Drosera rotundifolia at Paniai Lakes, Papua New Guinea: a Sphagnum swamp among montane dwarf forest. Plants of Nepenthes maxima can be spotted growing through the Rhododendron scrub on the left. The tallest darker bushes in the background (still not much more than $1 \mathrm{~m}$ ) are Papuacedrus papuana. The Drosera grows in the surrounding wet Sphagnum carpets with sedges and Xyris sp. (yellow flowers bottom right). Photo: Chien Lee.

observed variation in lamina shape in boreal $D$. rotundifolia populations is large, and the two known tropical populations on the Philippines and Papua New Guinea easily fall within that morphological range (Coritico \& Fleischmann 2016). In summary, the morphology of the tropical populations of D. rotundifolia does not justify separate taxonomic distinction (as suggested by Van Steenis 1955; see Coritico \& Fleischmann 2016, who synonymized D. rotundifolia var. bracteata Steen. with the nominal taxon). The leaf color pattern of the Philippine D. rotundifolia in cultivation looks different from wild populations at first sight (having in mind the bright red plants we know from temperate bogs), as the lamina of the active leaves remains bright yellowish-green even if exposed to bright light levels (only the petiole is vividly wine-red), starting to turn red from its middle only in aged, senescent leaves (Fig. 5C,D). However, that color pattern is identical to that observed in wild populations of tropical high-elevation bogs in the Philippines (Fig. 2) and in Papua New Guinea (Fig. 3). Actually, it is also the same in most Northern Hemisphere populations of D. rotundifolia if we have a closer look, as the newly developed and active leaves of that species always have a green lamina lined with bright red tentacles - only aged leaves of that species are turning fully red.

\section{Flowers and breeding}

Philippine D. rotundifolia have white anther thecae and pollen (Fig. 5E) like most of their North American and Asian congeners, while European populations frequently show pale yellow pollen. In 


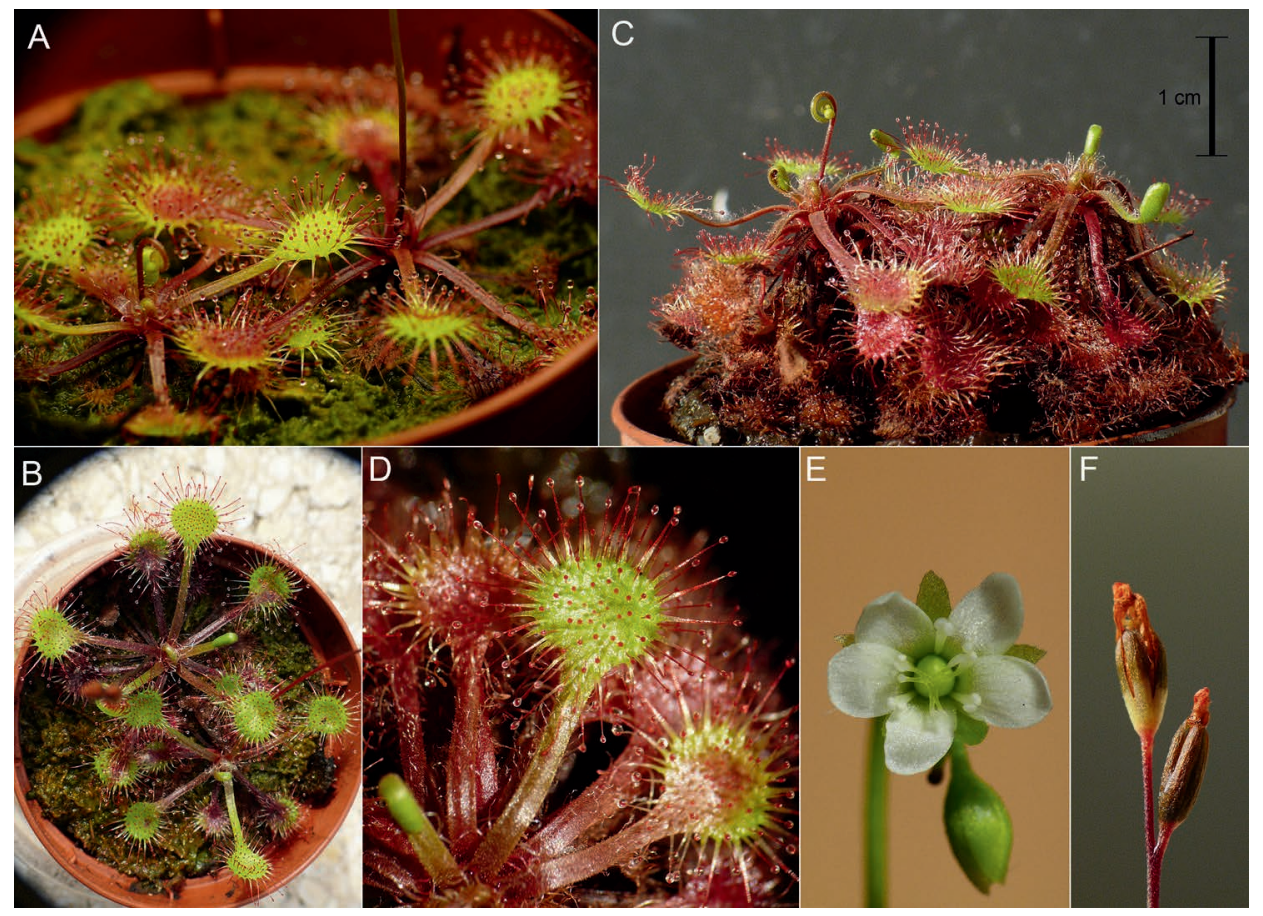

Figure 5: Cultivated D. rotundifolia of Philippine origin. A, B. first year of growth from seed. C. forming ca. $2 \mathrm{~cm}$ tall columns after 3.5 years of perennial growth. D. close-up of the leaves. E. flower at early anthesis, pollen sacs just beginning to split open. F. seed pods. Images not to scale. Photos: Andreas Fleischmann.

all other respects, the flowers are, however, identical. Exactly like in temperate $D$. rotundifolia, each individual flower of the Philippine plants will open only for a few hours in the late morning on a single day, and only under bright sunny conditions. Under high humidity in a closed terrarium, the petals will not spread open and the flowers self-pollinate cleistogamously. Under the author's growing conditions, seed set of the open, chasmogamous flowers was better, although the cleistogamous flowers also set viable seed (yet in lower number and with larger portion of aborted, sterile grains). In this respect, the facultatively cleistogamous species $D$. rotundifolia is perfectly pre-adapted for growing on a cool, foggy and rainy high montane tropical summit. Artificial cross-pollination with $D$. rotundifolia from German provenance produced viable seeds (reciprocal on both seed parents; anthers were removed before the thecae split open in order to avoid self-pollination). The resulting offspring generation is growing well (under tropical highland conditions), the plants have not flowered so far thus nothing can be said about fertility yet. A manmade cross with $D$. anglica from Hawai'i produced seed which germinated as well - hence "tropical $D . \times$ obovata" can theoretically be created - at least artificially, as both hybrid parents are naturally separated by ca. $8,600 \mathrm{~km}$ [5,400 mi] of Pacific Ocean.

Seeds and dispersal

Drosera rotundifolia seeds are perfectly adapted to wind-dispersal by their fusiform shape and extremely thin seed coat (the testa in this species is so thin that the dormant embryo inside shows 


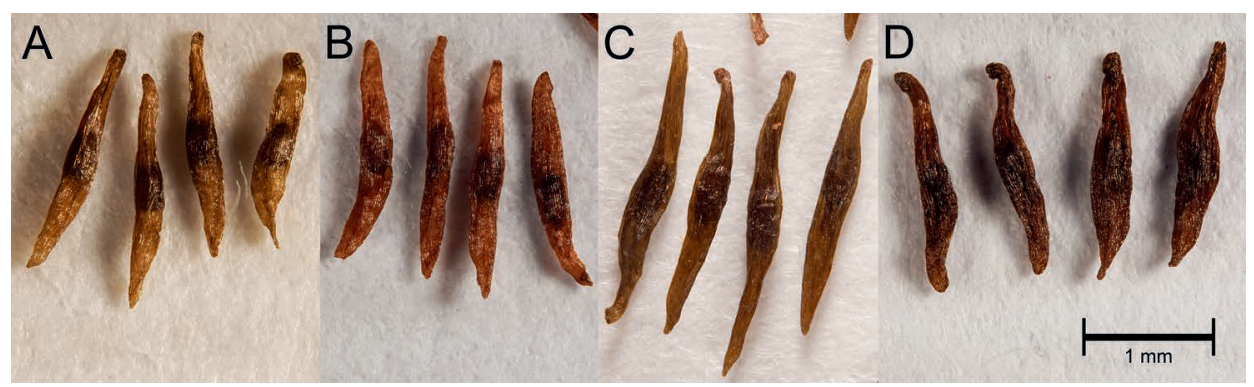

Figure 6: Comparison of D. rotundifolia seeds from different geographical origin. A. Chippewa County, Michigan, USA. B. Bavaria, Germany. C. Yakushima, Japan. D. Mindanao, Philippines. Fresh seeds, all at the same scale. Photos: Andreas Fleischmann.

through as dark elliptic structure in the center; Fig. 6) - in this respect, D. rotundifolia differs from all remaining Drosera species, which have much thicker, non-translucent seed coats. Only seeds of D. communis and D. grantsaui are similar to those of D. rotundifolia in this respect - three species with lightweight, short-lived seeds, comparable to those of orchids. Philippine $D$. rotundifolia have a slightly thicker testa and relatively shorter fusiform appendages (Fig. 6) compared to their more northern congeners - nevertheless it is the same species, but maybe just an adaptation to an isolated summit on an oceanic island. A small excursion on seed shape and wind dispersal on oceanic islands:

In oceanic island populations of plants, a secondary reduction or full loss of seed appendages or outgrowths that are normally used in anemochorous (wind-dispersed) plants for surface extension to increase lift for wind dispersal is frequently observed, often in quite short-term, i.e. in just a few generations time (Carlquist 1966; Cody \& Overton 1996). This phenomenon is interpreted as an adapted local dispersal strategy on wind-swept islands to avoid propagules being drifted away to the sea and drown (Cody \& Overton 1996; García-Verdugo et al. 2017), and interestingly it is paralleled in several lineages of winged insects which secondarily became flightless (so-called brachyptery or aptery, i.e. strongly reduced wings or fully wingless individuals) on oceanic islands for the very same reason (Roff 1990). Wide dispersal ability leads to greater seed loss on oceanic islands, hence in many cases special "oceanic island morphologies" that limit dispersal are selected by evolution (Cody \& Overton 1996). Or, the other way round, seed morphologies with more limited dispersal ability are retained there because they are not negatively selected against, as wide dispersal is of no use on oceanic islands (Carlquist 1966). The roundish, unusual seeds of the Seychelles islands endemic Nepenthes pervillei might come to mind here, which lack the characteristic fusiform shape and the filamentous appendages on both sides that are characteristic for the seed of all other $\mathrm{Ne}$ penthes species. Indeed, these unusual seeds can be taken as an example for adaptation to oceanic island conditions, however with $N$. pervillei being sister to all remaining Nepenthes species, this seed shape might as well represent the ancestral condition in the genus. The case of $D$. rotundifolia is different of course, as here this character is only found in a certain population of a given species in adaptation to oceanic island conditions; moreover, D. rotundifolia belongs to a more derived group of sundews.

Thus, many plants with wind-dispersed seed reach remote oceanic islands by wind-driven longdistance dispersal (perhaps also mediated by migratory birds). Yet, once arrived and established there, island populations often evolve away from dispersal by wind in order to stay where they are (the so-called "loss of dispersal ability hypothesis"; García-Verdugo et al. 2017; but see Burns 
2018 for counter-arguments). Such a case might have happened in the Philippine population of $D$. rotundifolia - a species with seeds normally very well-adapted to wind dispersal, being one of the Drosera species with the thinnest seed coat and longest filamentous testa appendages of its fusiform seeds. The Philippine population of that species in contrast has seeds with much thicker testa (as evident already by the darker brown color; Fig. 6) and slightly shorter appendages on both poles. In contrast, seed of the Hawai'ian populations of $D$. anglica does not differ notably from that of its mainland congeners - but that species seems to have a generally more reduced wind dispersal potential based on seed morphology. Seeds of D. rotundifolia from Yakushima island, Japan, do not show reduced seed appendages or thicker testa, in fact they are even slightly longer (Fig. 6), however that population occurs in a valley, not exposed on a wind-swept summit like the Philippine plants on Mt. Limbawon.

\section{Cultivation and dormancy}

Seed-grown plants of Philippine origin were kept under artificial lights in a terrarium under tropical conditions (photoperiod of 12 hours), with day temperatures between ca. $15-25^{\circ} \mathrm{C}(59$ $\left.77^{\circ} \mathrm{F}\right)$ and night temperatures of ca. $5-15^{\circ} \mathrm{C}\left(41-59^{\circ} \mathrm{F}\right)$ year-round (cooler room temperatures in winter, higher ones in summer). Under these conditions, the plants are growing continuously without forming any hibernacula for nearly four years now, flowering mainly during the cooler months. After anthesis and fruit set, the plants slow down growth, sometimes not producing new leaves for several weeks, but without formation of any resting organs (see also Snyder 2006 for an artificially created, perennially growing cultivar of $D$. rotundifolia). In contrast, plants of Philippine $D$. rotundifolia that were kept under natural light conditions started forming hibernacula by mid-autumn (the same growth pattern holds true for tropical D. anglica from Hawai'i and tropical D. intermedia from Venezuela and Brazil2), no matter if kept in the heated hothouse, in the coolhouse, or outdoors. Hence it seems obvious that the hibernacula formation in these temperate Drosera species is induced by a decrease in daylength, but not by temperature. Plants kept indoors in a terrarium under $12 \mathrm{hr}$ photoperiod never formed hibernacula, even when exposed to colder temperatures for prolonged time. Plants of Philippine D. rotundifolia that were kept outdoors in the summer 2018 also formed winter buds in autumn, but did not survive a cold dormancy during winter. Interestingly, plants of $D$. rotundifolia from subtropical climates, e.g. Yakushima island, Japan (at $30^{\circ} \mathrm{N}$, Köppen climate classification $C f a$ ), or Kagoshima, Japan (ca. $31^{\circ} \mathrm{N}, C f a$ ), or more southern US localities, if exposed to stable (tropical) light and temperature conditions in cultivation, will still form winter buds after some time of sustained perennial growth, and then eventually die arrested as winter bud (pers. obs., M. Hochberg, pers. com. 2007; Kagawa 2015 reports that some subtropical populations of D. rotundifolia in Japan that are exposed to hot summer temperatures in their habitats can grow as annuals). Hence a seasonal cold dormancy seems to be essential for the annual growth cycle and healthy growth of that temperate species. The Philippine tropical strain, in contrast, seems to be persistent under tropical cool highland conditions, never demanding for a dormancy.

Acknowledgements: Fernando Rivadavia, Seiji Hirano and Klaus Keller are thanked for providing seeds of D. rotundifolia from the USA and Japan, Fulgent Coritico and David Marwinski for report-

\footnotetext{
${ }^{2}$ The fact that the three temperate species that have outlying populations in tropical or subtropical regions all still show the ability to form winter buds indicates a) their evolutionary origin in the temperate (boreal) Northern Hemisphere and b) that their individual long-distance dispersals to the tropics have happened quite recently (see also Coritico \& Fleischmann 2016; Fleischmann et al. 2018).
} 
ing observations and sharing photographs of $D$. rotundifolia from Mindanao, Philippines, and Chien Lee for information and photographs of the species and its habitat from Papua New Guinea. Barry Rice and Jan Schlauer are thanked for helpful comments on the manuscript.

\section{References}

Assefa, A., Ehrich, D., Taberlet, P., Nemomissa, S., and Brochmann, C. 2007. Pleistocene colonization of afro-alpine 'sky islands' by the arctic-alpine Arabis alpina. Heredity 99(2): 133-142.

Baranyai, B., and Joosten, H. 2016. Biology, ecology, use, conservation and cultivation of roundleaved sundew (Drosera rotundifolia L.): a review. Mires and Peat 18(18): 1-28.

Burns, K.C. 2018. Time to abandon the loss of dispersal ability hypothesis in island plants. Journal of Biogeography 45(6): 1219-1222.

Carlquist, S. 1966. The biota of long-distance dispersal. II. Loss of dispersibility in Pacific Compositae. Evolution 20(1): 30-48.

Cody, M.L., and Overton, J.McC. 1996. Short-term evolution of reduced dispersal in island plant populations. Journal of Ecology 84(1): 53-61.

Coritico, F.P., and Fleischmann, A. 2016. The first record of the boreal bog species Drosera rotundifolia L. (Droseraceae) from the Philippines, and a key to the Philippine sundews. Blumea 61(1): 24-28.

Delange, A., and Hugot, L. (eds.) 2020. Atlas biogéographique de la flore de Corse. Conservatoire Botanique National de Corse \& Office de l'Environnement de la Corse. Albiana, Ajaccio, France. 608 pp.

Diels, L. 1906. Droseraceae. In: Engler, H.G.A. (ed.): Das Pflanzenreich 26(4): 1-136. Wilhelm Engelmann, Leipzig, Germany.

Eminağaoğlu, Ö., Kutbay, H.G., Özkan, Z.C., and Ergül, A. 2008. Flora of the Camili Biosphere Reserve area (Borçka, Artvin, Turkey). Turkish Journal of Botany 32(1): 43-90.

Fischer, E., Gröger, A., and Lobin, W. 2018. Illustrated Field Guide to the Flora of Georgia (South Caucasus). Universität Koblenz-Landau, Germany.

Fleischmann, A., Cross, A.T., Gibson, R., Gonella, P.M., and Dixon, K.W. 2018. Systematics and evolution of Droseraceae. In: Ellison, A.M., and Adamec, L. (eds.): Carnivorous Plants: Physiology, Ecology, and Evolution: 45-57. Oxford University Press, Oxford.

García-Verdugo, C., Mairal, M., Monroy, P., Sajeva, M., and Caujapé-Castells, J. 2017. The loss of dispersal on islands hypothesis revisited: Implementing phylogeography to investigate evolution of dispersal traits in Periploca (Apocynaceae). Journal of Biogeography 44(11): 2595-2606.

Hultén, E. 1971. The circumpolar plants. Vol. 2, Dicotyledons. Kungl. Svenska vetenskapsakademiens handlingar 4:13:1. Almqvist and Wiksell, Stockholm, Sweden.

Kagawa, T. 2015. Drosera of Japan. CreateSpace Independent Publishing Platform. 63 pp.

Lorite, J. 2016. An updated checklist of the vascular flora of Sierra Nevada (SE Spain). Phytotaxa 261(1): 1-57.

Lu, L., and Kondo, K. 2001. Droseraceae. In: Wu, Z.Y., and Raven, P.H. (eds.): Flora of China, Vol. 8: 199-201. Science Press, Beijing \& Missouri Botanical Garden Press, St. Louis.

Maurizio, R. 2009. Flora des Bergell mit Andeutung der Grenzgebiete. Boissiera 62: 1-370.

Meusel, H., Jäger, E.J., and Weinert, E. 1965. Vergleichende Chorologie der zentraleuropäischen Flora. Text und Karten, Vol. 1. VEB Fischer, Jena, Germany.

Paiva, J. 1997. Droseraceae. In: Castroviejo, S. et al. (eds.): Flora Iberica, Vol. 5: 74-80. Madrid, Spain.

Rice, B.A. 2019. The genus Drosera L. (Droseraceae) in the western USA. Phytologia 101(1): 25-37. 
Rice, B.A., Robinson, A.S., and Fleischmann, A. 2017. Drosera of North America. In: Lowrie, A. et al., Drosera of the World. Vol. 2, Oceania, Asia, Europe, North America: 970-1027. Redfern Natural History Publications, Dorset, UK.

Robinson, A.S., Fleischmann, A., and Nunn, R. 2017. Drosera of Asia. In: Lowrie, A. et al., Drosera of the World. Vol. 2, Oceania, Asia, Europe, North America: 907-969. Redfern Natural History Publications, Dorset, UK.

Roff, D.A. 1990. The evolution of flightless insects. Ecological Monographs 60(4): 389-421.

Schnell, D. 2002. Carnivorous plants of the United States and Canada. Timber Press, Portland, USA. Snyder, I. 2006. Drosera rotundifolia ‘Charles Darwin'. Carnivorous Plant Newsletter 35(3): 68-69. Taylor, P. 1977. Lentibulariaceae. Flora Malesiana, Series I, 8(2): 275-300.

Theodoropoulos, K., and Eleftheriadou, E. 2012. Drosera rotundifolia L. (Droseraceae). A rare and endangered species for the flora of Greece. Journal of Environmental Protection and Ecology 13(3): 1405-1411.

Tohmé, G., and Tohmé, H. 2007. Illustrated Flora of Lebanon. CNRS Publications, Beirut, Lebanon. Van Steenis, C.G.G.J. 1955. Miscellaneous notes on New Guinea plants II. Nova Guinea 6(2): 279282.

Van Steenis, C.G.G.J. 1962. The mountain flora of the Malaysian tropics. Endeavour 21: 183-193.

Vidal-Russell, R., Fernández-Cánepa, G., Nuñez, C.I., and Ezcurra, C. 2019. First report of alien Drosera rotundifolia in a high conservation value Patagonian peat bog. Weed Research 59: 458466.

Walker, R. 2015. Carnivorous Plant Database. http://www.omnisterra.com/bot/cp_home.cgi [accessed 30.11.2020]

Wallnöfer, B., and Vitek, E. 1999. Die Gattung Drosera (Droseraceae) in Österreich. Annalen des Naturhistorischen Museums Wien 101, B: 631-660.

Wolf, E., Gage, E., and Cooper, D.J. 2006. Drosera rotundifolia L. (roundleaf sundew): a technical conservation assessment. USDA Forest Service, Rocky Mountain Region.

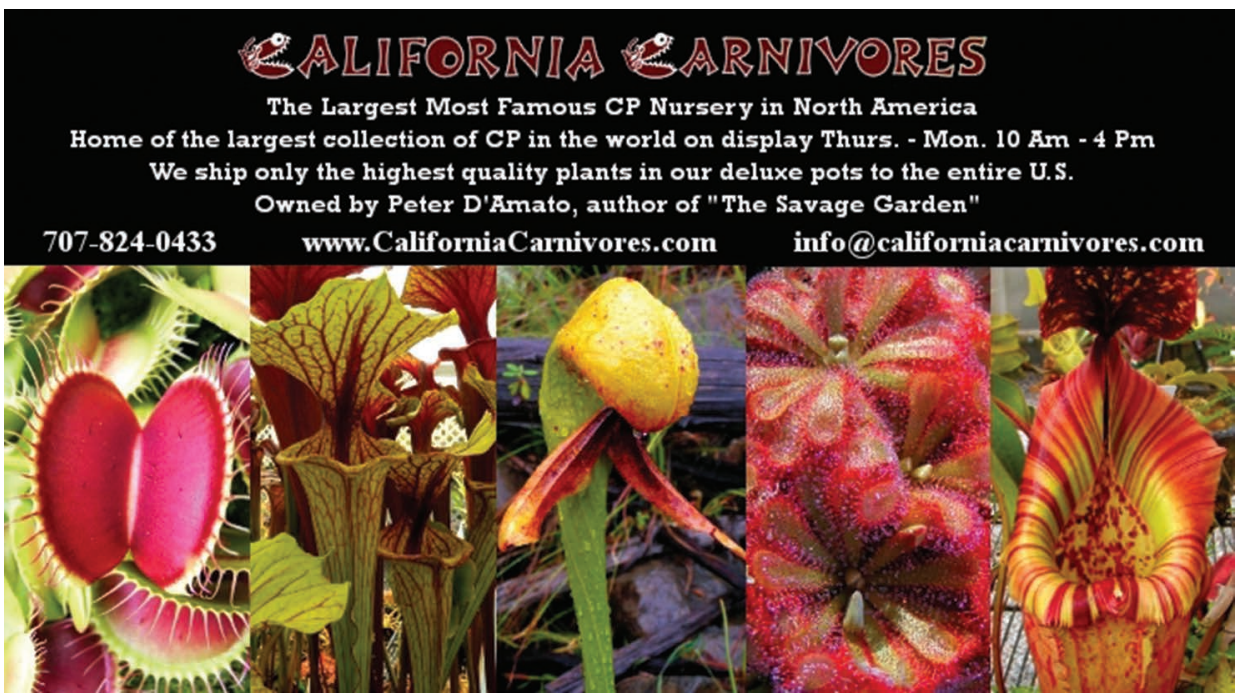




\section{CARNIVOROUS PLANT NEWSLETTER}

Journal of the International Carnivorous Plant Society

Volume 50, No. 1

March 2021

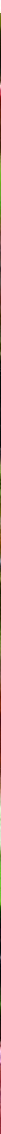

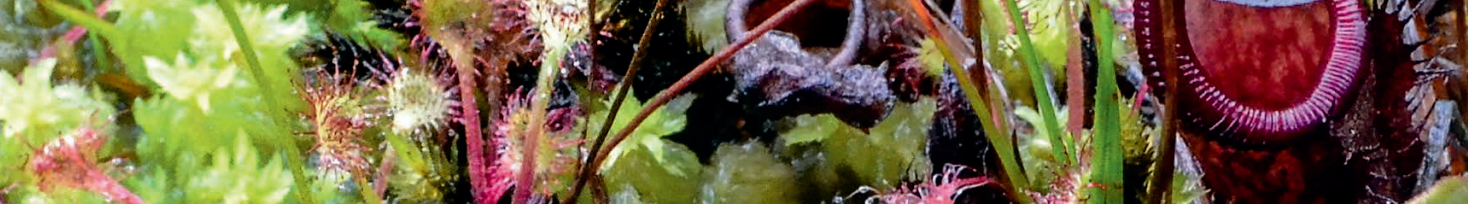

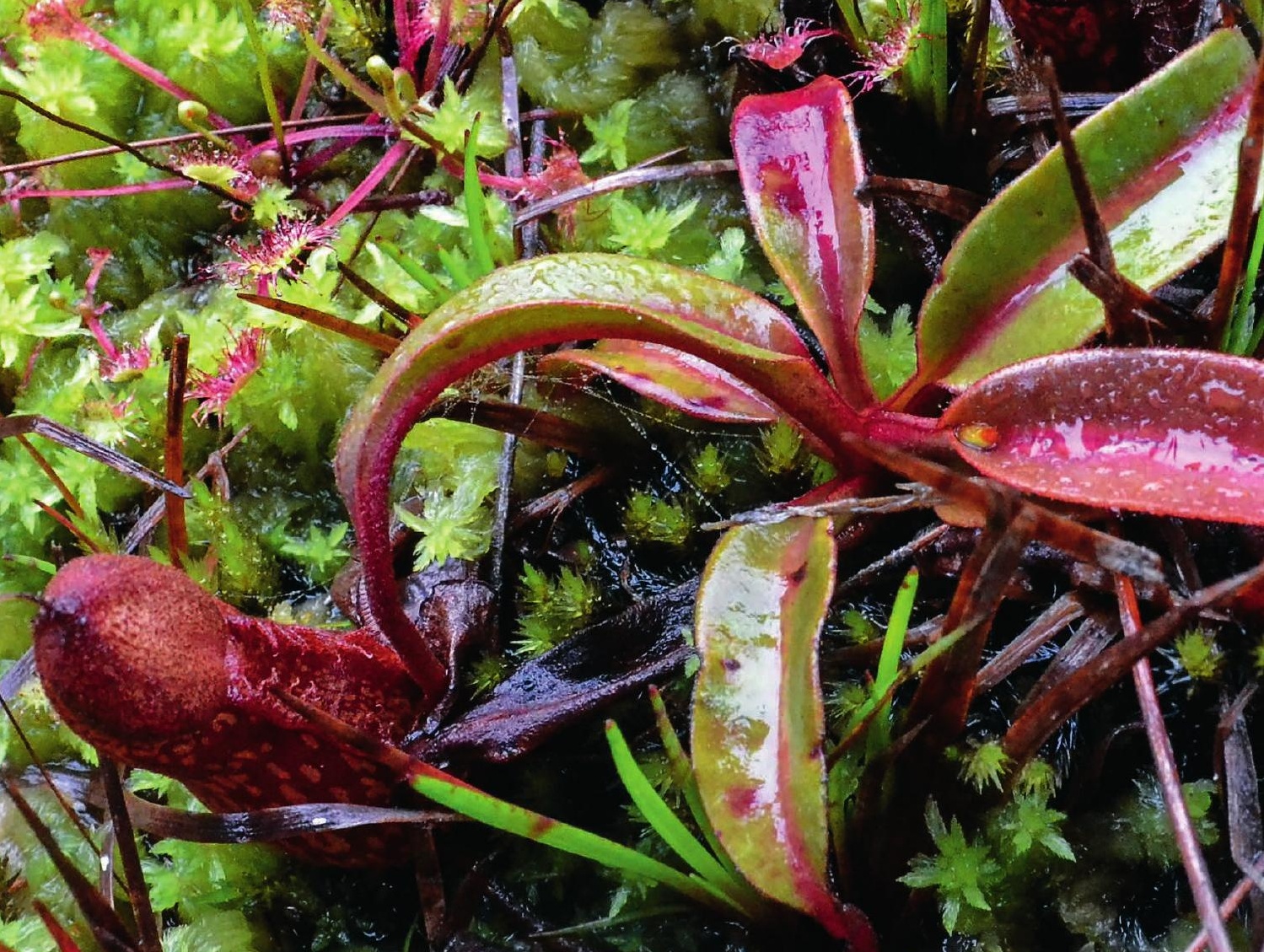

- 1 


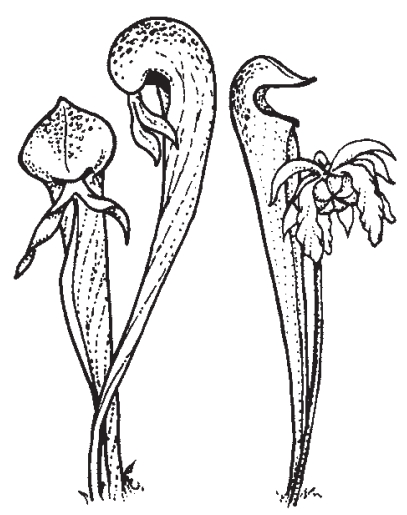

\section{CARNIVOROUS \\ PLANT \\ NEWSLETTER}

Journal of the International

Carnivorous Plant Society

www.carnivorousplants.org

\section{Volume 50, Number 1 March 2021}

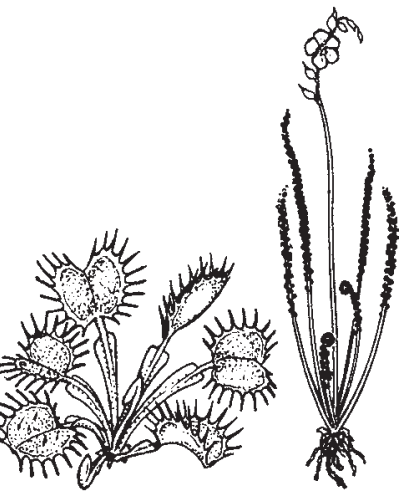

Front Cover: Drosera rotundifolia growing with a juvenile Nepenthes pulchra in a tropical montane peat bog in the Philippines. Photo by Fulgent Coritico. Article on page 7.

Back Cover: Drosera lusitanicum leaf unfurling. Photo by Barry Rice. Article on page 29.

Carnivorous Plant Newsletter is dedicated to spreading knowledge and news related to carnivorous plants. Reader contributions are essential for this mission to be successful. Do not hesitate to contact the editors with information about your plants, conservation projects, field trips, or noteworthy events. Advertisers should contact the editors. Views expressed in this publication are those of the authors, not the editorial staff.

All correspondence regarding dues, address changes and missing issues should be sent to the Membership Coordinator at the ICPS. Do not send such correspondence to the editors. Checks for subscriptions should be made to the International Carnivorous Plant Society in US funds. Dues, including a subscription, are \$35 per year.

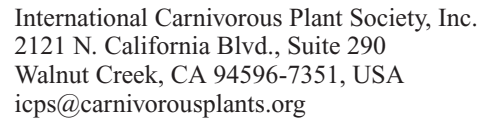

President

Vice President

Secretary

Treasurer

Board Member

Board Member

Board Member

Board Member

Board Member

Membership Coordinator

Webmaster

Media Coordinator

Seed Bank Manager

Facebook Manager

\begin{abstract}
Richard Nunn, richardnunn@carnivorousplants.org John Brittnacher, john@carnivorousplants.org Cindy Slezak, cindy@carnivorousplants.org Daniela Ribbecke, daniela@carnivorousplants.org Kenny Coogan, Education Director, kenny@carnivorousplants.org Brent Jones, brent@carnivorousplants.org Jan Schlauer, Cultivar Registrar, jan@carnivorousplants.org Cason Trexler, Conservation Director, carson@carnivorousplants.org Bob Ziemer, bob@carnivorousplants.org
\end{abstract}

Cindy Slezak, cindy@carnivorousplants.org John Brittnacher, john@carnivorousplants.org ChadWilliams, chad@carnivorousplants.org Joe Griffin, joe@carnivorousplants.org Marcel van den Broek, marcel@carnivorousplants.org
CPN Editors

Managing Editor

Editor

Editor

Editor editor@carnivorousplants.org
Bob Ziemer
Barry Rice
Karl Herold
Science Editor
Science Editor
Science Editor
Andreas Fleischmann
Fernando Rivadavia
Jan Schlauer

John Brittnacher

Date of effective publication of the December 2020 issue of Carnivorous Plant Newsletter: November 23, 2020.

The ICPS is the International Cultivar Registration Authority (ICRA) for the names of cultivated carnivorous plants according to the International Code of Nomenclature for Cultivated Plants. Send relevant correspondence to the ICPS, Inc.

Carnivorous Plant Newsletter is published quarterly in March, June, September, and December by the ICPS, Inc., 2121 N. California Blvd., Suite 290, Walnut Creek, CA 94596, USA. Periodicals postage paid at Walnut Creek, CA and additional mailing offices. Postmaster: Send address changes to ICPS, Inc., 2121 N. California Blvd., Suite 290, Walnut Creek, CA 94596, USA. Printed by Allen Press, Inc., 810 E. 10th Street, Lawrence, KS 66044. Logo and masthead art: Paul Milauskas. (C) 2021 International Carnivorous Plant Society. All rights reserved. ISSN \#0190-9215 